\title{
Pengaruh Model Pembelajaran Problem Based Learning terhadap Sikap Mandiri dan Kemampuan Komunikasi Matematika Siswa Kelas V SD Negeri Bakalrejo 1
}

\author{
Erika Muninggar Safitri ${ }^{*}$, Yunita Sari $^{2}$, Rida Fironika Kusuma Dewi ${ }^{3}$ \\ 1,2,3 PGSD Unissula \\ *erikasafitri66@gmail.com
}

\begin{abstract}
ABSTRAK
Penelitian ini bertujuan untuk mengetahui: (1) apakah ada pengaruh model pembelajaran problem based learning terhadap sikap mandiri siswa kelas V SD Negeri Bakalrejo 1; (2) Aapakah ada pengaruh model pembelajaran problem based learning terhadap kemampuan komunikasi matematika siswa kelas V SD Negeri Bakalrejo 1; dan (3) apakah ada pengaruh model pembelajaran problem based learning terhadap sikap mandiri dan kemampuan komunikasi matematika siswa kelas V SD Negeri Bakalrejo 1. Jenis penelitian yang digunakan yaitu nonequivalent control group design. Hasil perhitungan hipotesis I menggunakan rumus independent sample $t$ test nilai perhitungan menggunakan SPSS 16 dengan nilai signifikansi pada kolom sig.(2-tailed) sebesar 0,000 yang berarti model problem based learning berpengruh terhadap sikap mandiri siswa. Hipotesis II menggunakan rumus independent sample $t$ test nilai perhitungan menggunakan SPSS 16 dengan nilai signifikansi pada kolom sig.(2-tailed) sebesar 0,000 berarti ada pengaruh model pembelajaran problem based learning terhadap kemampuan komunikasi matematika siswa. Hasil perhitungan hipotesis III menggunakan uji manova menunjukkan bahwa hasil analisis untuk Pillai's Trace, Wilks' Lambda, Hotelling's Trace,Roy's Largest Root semuanya menunjukkan nilai sebesar 0,000 karena signifikansi kurang dari 0,05 berarti ada pengaruh model pembelajaran problem based learning terhadap sikap mandiri dan kemampuan komunikasi matematika siswa siswa kelas V SD Negeri Bakalrejo 1.
\end{abstract}

Kata Kunci: model problem based learning, kemampuan komunikasi matematika, sikap mandiri siswa.

\begin{abstract}
This study aims to determine: (1) is there an influence of the problem based learning model of learning towards the independent attitude of fifth grade students of SD Negeri Bakalrejo 1; (2) is there an effect of the problem based learning model on the mathematical communication skills of fifth grade students at Bakalrejo 1 Public Elementary School; and (3) is there any influence of the problem based learning model on independent attitude and mathematical communication skills of fifth grade students at Bakalrejo State Elementary School 1. The type of research used is Nonequivalent control group design. The results of the calculation of hypothesis I use the formula of independent sample t test value calculation using SPSS 16 with a significance value in the column sig. (2-tailed) of 0,000, which means the problem based learning model affects the independent attitude of students. Hypothesis II uses the formula of independent sample t test calculation value using SPSS 16 with a significance value in column sig. (2-tailed) of 0,000, which means there is an influence of problem based learning learning model on students' mathematical communication skills. The results of calculation of hypothesis III using the manova test showed that the analysis results for Pillai's Trace, Wilks' Lambda, Hotelling's Trace, Roy's Largest Root all showed values of 0,000 because the significance is less than 0.05 meant that there was an influence of problem based learning models learning towards independent attitudes and mathematical communication skills of students of fifth grade SD Bakalrejo 1.
\end{abstract}

Keywords: problem based learning model, mathematical communication skills, students' independent attitude. 


\section{PENDAHULUAN}

Perkembangan zaman dan teknologi di dunia saat ini berkembang semakin pesat, sehingga menuntut manusia untuk meningkatkan kualitasnya terutama dalam dunia pendidikan. Belajar matematika merupakan syarat untuk melanjutkan pendidikan ke jenjang yang lebih tinggi. Karena dengan belajar matematika, kita dapat bernalar secara kritis, kreatif, dan aktif. Matematika merupakan ide-ide abstrak yang berisi simbol-simbol, maka konsep-konsep matematika harus dipahami terlebih dahulu sebelum memanipulasi simbol-simbol itu. National Council of Teacher Mahematic (Fahradina et al., 2014) menyatakan tujuan pembelajaran matematika yaitu (1) belajar untuk berkomunikasi (mathematical communication); (2) belajar untuk bernalar (mathematical reasoning); (3) belajar untuk memecahkan masalah (mathematical problem solving); (4) belajar untuk mengaitkan ide (mathematical connections); (5) pembentukan sikap positif terhadap matematika (positive attitude towards mathematics). Salah satu tujuan pembelajaran matematika menurut NCTM yaitu belajar untuk berkomunikasi.

Kemampuan komunikasi matematis merupakan kemampuan yang terdapat pada diri siswa untuk menyampaikan ide matematika baik secara lisan maupun tulisan. Menurut Prayitno dkk. (Hodiyanto, 2017) komunikasi matematis adalah suatu cara siswa untuk menyatakan dan menafsirkan gagasan-gagasan matematika secara lisan maupun tertulis, baik dalam bentuk gambar, tabel, diagram, rumus, ataupun demonstrasi. Kemampuaan komunikasi matematika saat ini masih tergolong rendah. Hal ini disebabkan saat pembelajaran matematika masih berpusat pada guru dan saat pembelajaran guru masih menggunakan pembelajaran konvensional sehingga membuat pembelajaran mejadi monoton dan kurang menarik.

Proses pembelajaran yang berpusat pada guru menyebabkan siswa cenderung bersifat pasif dan siswa kurang antusias dan kreatif saat pembelajaran. Siswa yang tidak terlibat aktif dalam pembelajaran menyebabkan siswa sulit untuk memberi penjelasan yang benar, jelas, dan logis dan siswa sulit untuk menyampaikan ide-ide yang mereka miliki baik kepada guru maupun temannya. Pembelajaran yang masih berpusat pada guru juga mengakibatkan siswa masih bergantung pada guru saat proses pembelajaran berlangsung dan menyebabkan siswa kurang mandiri saat belajar.

Kemandirian belajar merupakan hal terpenting yang harus dimiliki seorang siswa. Menurut Alben Ambarita (Wulandari, 2015) mengemukakan bahwa kemandirian akan menentukan sikap seorang siswa yang ditunjukkan oleh perilaku yang berkaitan dengan pengolaan diri (self management), pengarahan diri (self governance), dan pengontrolan diri (personal control). Menurut Panen ciri utama dalam belajar mandiri bukan adanya ketiadaan guru atau teman sesama siswa, atau tidak adanya pertemuan tatap muka di kelas, melainkan adanya pengembangan kemampuan siswa untuk melakukan proses belajar yang tidak bergantung kepada guru, teman, kelas, dan lain-lain (Nuridawani, Munzir, \& Saiman, 2015).

Tingkat kemandirian belajar siswa dapat di tentukan berdasarkan seberapa inisiatif dan tanggung jawab siswa untuk berperan aktif dalam hal perencanaan belajar, proses belajar, maupun evaluasi belajar.Semakin besar peran aktif siswa dalam kegiatan, hal tersebut membuktikan bahwa siswa memiliki kemandirian belajar yang tinggi.Tingkat kemandirian belajar berkaitan dengan tingkat perkembangan siswa.

Penyebab rendahnya sikap mandiri dan kemampuan komunikasi matematika pada siswa

yaitu guru masih menggunakan pembelajaran konvensional yang hanya berpusat pada guru 
saja, sehingga siswa menjadi pasif dan kurang antusias pembelajaran. Menyadari akan pentingnya sikap mandiri dan kemampuan komunikasi matematika dalam belajar, guru harus mengupayakan pembelajaran dengan menerapkan model-model pembelajaran yang dapat mendorong siswa untuk melatih kemandirian dan komunikasi matematika siswa.

Problem Based Learning (PBL) merupakan salah satu model pembelajaran kooperatif yang dapat memberikan pembelajaran aktif kepada siswa. Yatim Riyanto menyatakan bahwa PBL memfokuskan pada siswa dengan mengarahkan siswa menjadi pembelajar yang mandiri dan terlibat langsung secara aktif dalam pembelajaran kelompok (Wulandari, 2015). Pembelajaran $P B L$ dilakukan dengan cara memberikan suatu masalah kepada siswa dan siswa bekerjasama secara berkelompok untuk menyelesaikan masalah yang diberikan. Dengan demikian siswa mampu berkomunikasi sesama temannya dan bertukar pikiran ataupun informasi dengan anggota kelompoknya untuk membangun pengetahuan. Dalam pembelajaran problem based lerning guru berperan sebagai fasilitator yang memfasiltasi belajar siswa, sehingga siswa dilatih tidak menggantungkan kegiatan pembelajaran sepenuhnya pada guru, sehingga kemandirian belajar dalam diri siswa akan muncul.

Berdasarkan permasalahan yang telah dijabarkan di atas, peneliti mecoba untuk meneliti apakah terdapat pengaruh model PBL terhadap sikap mandiri dan komunikasi matematika. Maka peneliti mengambil judul "Pengaruh Model Pembelajaran Problem Based Learning Terhadap Sikap Mandiri dan Komunikasi Matematika Siswa Kelas V SD Negeri Bakalrejo 1".

Rumusan masalah dalam penelitian ini yaitu: (1) apakah ada pengaruh model pembelajaran problem based learning terhadap sikap mandiri siswa kelas V SD Negeri Bakalrejo 1; (2) apakah ada pengaruh model pembelajaran problem based learning terhadap kemampuan komunikasi matematika siswa kelas V SD Negeri Bakalrejo 1; (3) apakah ada pengaruh model pembelajaran problem based learning terhadap sikap mandiri dan kemampuan komunikasi matematika siswa kelas V SD Negeri Bakalrejo 1.

Adapun tujuan penelitian ini yaitu: (1) untuk mengetahui apakah ada pengaruh model pembelajaran problem based learning terhadap sikap mandiri siswa kelas V SD Negeri Bakalrejo 1; (2) untuk mengetahui apakah ada pengaruh model pembelajaran problem based learning terhadap kemampuan komunikasi matematika siswa kelas V SD Negeri Bakalrejo 1; (3) untuk mengetahui apakah ada pengaruh model pembelajaran problem based learning terhadap sikap mandiri dan kemampuan komunikasi matematika siswa kelas V SD Negeri Bakalrejo 1.

\section{METODE}

\subsection{Jenis Penelitian}

Penelitian ini menggunakan pendekatan kuantitatif dengan metode penelitian eksperimen dengan mengunakan desain penelitian Quasi Eksperimental Design dengan rancangan peneltian Nonequivalent Control Group Design. Paradigma pada penelitian ini dapat di gambarkan sebagai berikut. 
Keterangan:

$\mathrm{O}_{1}$ : keadaan kelompok eksperimen sebelum di beri perlakuan

$\mathrm{O}_{2}$ : keadaan kelompok eksperimen setelah di beri perlakuan

$\mathrm{X}$ : perlakuan yang di berikan menggunakan model problem based learning.

$\mathrm{O}_{3}$ : keadaan kelompok kontrol sebelum di beri perlakuan

$\mathrm{O}_{4}$ : keadaan kelompok kontrol setelah di beri perlakuan tanpa menggunakan model problem based learning.

(Sugiyono, $2015: 116$ )

\subsection{Populasi dan Sampel}

Populasi dalam penilitian ini yaitu seluruh siswa kelas V SD Negeri Bakalrejo 1 tahun ajaran 2018/2019 yang terdiri kelas VA yang berjumlah 23 siswa dan VB berjumlah 23 siswa. Teknik pengambilan sampel yang di gunakan yaitu teknik sampling jenuh. Sampel yang di gunakan dalam penelitian ini yaitu kelas V A dan kelas V B.

\subsection{Teknik Pengumpulan Data}

Teknik pengumpulan data dalam penelitian ini yaitu tes, angket, dan dokumentasi. Tes bertujuan untuk mengukur kemampuan komunikasi matematika. Angket digunakan untuk mengukur sikap mandiri siswa. Dokumentasi digunakan untuk mendapatkan data-data bukti penelitian.

\subsection{Instrumen Penelitian}

Instrumen penelitian yang digunakan yaitu lembar tes kemampuan komunikasi matematika, lembar angket sikap mandiri dan dokumentasi.

\subsection{Teknik Analisis Data}

Analisis data yang digunakan dalam penelitian ini yaitu: (1) uji normalitas gunakan untuk mengetahui data yang akan dianalisis berdistribusi normal atau tidak normal; (2) uji homogenitas digunakan untuk mengetahui bahwa data awal sampel berasal dari populasi yang memiliki varians sama (homogen); (3) uji kesamaan dua rata-rata dilakukan untuk mengetahui kesamaan kemampuan awal dari dua kelas sampel, setelah data diketahui berdistribusi normal serta mempunyai varians yang homogen.

\section{HASIL DAN PEMBAHASAN}

\subsection{Analisis Data Awal}

Analisis data awal dilakukan sebelum penelitian, tujuan analisis data awal yaitu untuk mengetahui kemampuan awal kelas eksperimen dan kelas kontrol. Data yang akan dianalisis yaitu data hasil tes awal (pretest). Analisis data awal dalam penelitian ini adalah sebagai berikut.

\section{Uji Normalitas}

Uji normalitas digunakan untuk mengetahui apakah data yang dianalisis berdistribusi normal atau tidak normal. Penelitian ini menggunakan uji liliefors dengan bantuan program SPSS 16. Hasil uji normalitas data daapat dilihat pada Tabel 1. 
Tabel 1. Uji Normalitas Data Awal Kelas Eksperimen dan Kelas Kontrol

\begin{tabular}{ccc}
\hline Data & Kelas & Nilai Signifikansi \\
\hline Pretest & Eksperimen & 0,292 \\
& Kontrol & 0,282 \\
\hline
\end{tabular}

Berdasarkan Tabel 1, nilai signifikansi kelas eksperimen lebih dari 0,05 $(0,292>0,05)$ dan kelas kontrol nilai signifikansi lebih dari $0.05(0,282>0,05)$. Dari data tersebut dapat disimpulkan bahwa kedua kelas dinyatakan berdistribusi normal karena nilai signifikansinya lebih dari 0,05 .

\section{Uji Homogenitas}

Uji homogenitas digunakan untuk mengetahui apakah sampel dari data yang telah diambil homogen atau tidak. Hasil uji homogenitas dapat dilihat pada Tabel 2 di bawah ini.

Tabel 2.Uji Homogenitas Data Awal Kelas Eksperimen dan Kelas Kontrol

\begin{tabular}{cccc}
\hline Data & df1 & df2 & Sig \\
\hline Pretest & 1 & 44 & 0,717 \\
\hline
\end{tabular}

Berdasarkan Tabel 2 tersebut dapat diketahui bahwa nilai signifikansi pada kolom Sig sebesar 0,717. Nilai signifikansi tersebut lebih dari 0,05 $(0,717>0,05)$. Dari data tersebut dapat disimpulkan bahwa kedua kelas dinyatakan sama (homogen).

\section{Uji Kesamaan Dua Rata-Rata}

Uji kesamaan dua rata-rata dilakukan untuk mengetahui apakah sampel mempunyai kesamaan rata-rata atau tidak. Apabila tidak terdapat perbedaan berarti sampel memiliki kondisi yang sama. Hasil uji kesamaan dua rata-rata dapat dilihat pada Tabel 3.

Tabel 3.Uji Kesamaan Dua Rata-rata Kelas Eksperimen dan Kontrol

\begin{tabular}{cccc}
\hline & T & Df & Sig (2-tailed) \\
\hline Equal variance assumed & $-0,438$ & 44 & 0.664 \\
\hline
\end{tabular}

Berdasarkan Tabel 3 nilai signifikansi pada kolom sig (2-tailed) sebesar 0,664. Nilai signifikansi dari data tersebut lebih besar dari 0,05 ( 0,664 > 0,05), jika sig > 0,05 maka tidak terdapat ada perbedaan yang signifikan. Artinya tidak ada perbedaan kemampuan awal antara kelas kelas eksperimen dan kelas kontrol.

\subsection{Analisis Data Akhir}

Analisis data akhir digunakan untuk menguji hipotesis. Data akhir yang akan dianalisis yaitu tes kemampuan komunikasi matematika siswa dan angket kemandirian siswa.

\section{Uji Normalitas}

Uji normalitas data akhir digunakan untuk mengetahui apakah kelas eksperimen dan kelas kontrol, yang telah diberi perlakuan pembelajaran model problem based learning (kelas eksperimen) dan kelas yang menggunakan model konvensional (kelas kontrol) berdistribusi normal atau tidak. Hasil uji normalitas data akhir dapat di lihat pada Tabel 4. 
Tabel 4. Hasil Uji Normalitas DataAkhir Sikap Mandiri dan Kemampuan Komunikasi Matematika

\begin{tabular}{lcc}
\hline \multirow{2}{*}{ Data } & \multicolumn{2}{c}{ Nilai Signifikansi } \\
\cline { 2 - 3 } & Kelas Eksprimen & Kelas Kontrol \\
\hline Posttest Sikap Mandiri & 0,603 & 0,071 \\
Posttest Kemampuan komunikasi Matematika & 0,072 & 0,322 \\
\hline
\end{tabular}

Berdasarkan Tabel 4 menunjukkan bahwa data posttest sikap mandiri dan kemampuan komunikasi matematika pada kelas eksperimen dan kelas kontrol mempunyai nilai signifikansi lebih besar dari 0,05 yang berarti data tersebut bersidtribusi normal.

\section{Uji Homogenitas}

Uji homogenitas data dilakukan apabila data berdistribusi normal. Jika data tidak berdistribusi normal maka tidak perlu menguji homogenitasnya. Hasil output uji homogenitas dapat dilihat pada Tabel 5 di bawah ini.

\begin{tabular}{cccc}
\multicolumn{4}{c}{ Tabel 5. Hasil Uji Homogenitas Data Akhir } \\
\hline Data & df1 & df2 & Sig \\
\hline Postest Sikap Mandiri & 1 & 44 & 0,388 \\
Posttest Kemampuan komunikasi & 1 & 44 & 0,254 \\
Matematika & & & \\
\hline
\end{tabular}

Berdasarkan pada Tabel 5 dapat diketahui bahwa nilai signifikasi pada data sikap mandiri mendapat nilai sig $>0,05(0,388>0,05)$ dan kemampuan komunikasi matematika mendapat nilai sig $>0,05(0,254>0,05)$. Dari data tersebut dapat disimpulkan bahwa data bersifat homogen.

\section{Uji Hipotesis}

Hipotesis I: "Pengaruh model pembelajaran problem based learning terhadap sikap mandiri siswa kelas V SD Negeri Bakalrejo 1"

Kriteria pengujian: Jika sig $<\alpha$ maka Ho di tolak

Jika sig $>\alpha$ maka Ho di terima

Berdasarkan pengolahan data menggunkan uji independent sample t-test diketahui bahwa nilai signifikansi yang diperoleh yaitu sig $<0,05(0,000<0,05)$, karena sig $<0,05$ maka Ha diterima. Jadi dapat disimpulkan bahwa ada pengaruh model pembelajaran problem based learning terhadap sikap mandiri siswa kelas V SD Negeri Bakalrejo 1.

Hipotesis II: "Pengaruh model pembelajaran problem based learning terhadap kemampuan komunikasi matematika siswa kelas V SD Negeri Bakalrejo 1"

Kriteria pengujian: Jika sig $<\alpha$ maka Ho di tolak

Jika sig $>\alpha$ maka Ho di terima

Berdasarkan pengolahan data menggunkan uji independent sample t-test dengan taraf signifikan $\alpha=0,05$ diperoleh nilai signifikansi sebesar $(0,000<0,05)$, karena sig $<0,05$ maka Ha diterima. Jadi dapat disimpulkan bahwa ada pengaruh model pembelajaran problem based learning terhadap kemampuan komunikasi matematika siswa kelas V SD Negeri Bakalrejo 1. 
Hipotesis III: "Pengaruh model pembelajaran problem based learning terhadap sikap mandiri dan kemampuan komunikasi matematika siswa kelas V SD Negeri Bakalrejo 1"

Kriteria Pengujian: Jika sig $<\alpha$ maka Ho di tolak

Jika sig $>\alpha$ maka Ho di terima

Uji hipotesis ketiga ini menggunakan uji multivariate (Manova) diperoleh nilai signifikansi semuanya menunjukkan nilai sebesar 0,000. Dalam kriteria jika sig $<0,05$ maka Ha diterima maka dapat disimpulkan bahwa ada pengaruh model pembelajaran problem based learning terhadap sikap mandiri dan kemampuan komunikasi matematika siswa kelas V SD Negeri Bakalrejo 1.

\section{SIMPULAN}

Berdasarkan hasil uji hipotesis dapat disimpulkan sebagai berikut. (1) Ada pengaruh model pembelajaran problem based learning terhadap sikap madiri siswa kelas V SD Negeri Bakalrejo 1. Hal ini dibuktikan dengan adanya perbedaan rata-rata sikap mandiri siswa kelas eksperimen sebesar $(82,04)$ sedangkan pada kelas kontrol mendapat rata-rata sebesar 70,35. Pada perhitungan SPSS 16 nilai signifikansi pada kolom sig.(2-tailed) sebesar 0,000. Nilai signifikansi tersebut lebih kecil dari $0,05(0,000<0,05)$. (2) Ada pengaruh model pembelajaran problem based learning terhadap kemampuan komunikasi matematika siswa kelas V SD Negeri Bakalrejo 1. Hal ini dibuktikan dengan adanya perbedaan rata-rata kemampuan komunikasi matematika siswa kelas eksperimen sebesar (85.65) sedangkan pada kelas kontrol mendapat rata-rata sebesar (74.78). Pada perhitungan SPSS 16 nilai signifikansi pada kolom sig.(2-tailed) sebesar 0,000. Nilai signifikansi tersebut lebih kecil dari 0,05 $(0,000<0,05)$. (3) Ada pengaruh model pembelajaran problem based learning terhadap sikap mandiri dan kemampuan komunikasi matematika siswa kelas V SD Negeri Bakalrejo 1. Hal ini dibuktikan bahwa hasil analisis untuk Pillai's Trace, Wilks' Lambda, Hotelling's Trace,Roy's Largest Root semuanya menunjukkan nilai sebesar 0,000 karena signifikansi $<0,05(0,000<0,05)$.

\section{DAFTAR PUSTAKA}

Fahradina, N., Ansari, B. I., \& Saiman. (2014). Peningkatan Kemampuan Komunikasi Matematis dan Kemandirian Belajar Siswa SMP dengan Menggunakan Model Investigasi Kelompok.Jurnal Didaktik Matematika, 1(1).

Hodiyanto. (2017). Kemampuan Komunikasi Matematis dalam Pembelajaran Matematika. AdMathEdu,7(1).

Sugiyono. (2015). Metode Peneltian Pendidikan : Pendekatan Kuantitatif, Kualitatif, dan $R \&$ $D$. Bandung: Alfabeta.

Wulandari, E. T. (2015). Pengaruh Problem Based Learning Terhadap Kemandirian Belajar IPA Siswa Kelas IV SD Se-Gugus III Temon. Jurnal Pendidikan Guru Sekolah Dasar Edisi 12 Tahun Ke IV Agustus 2015.

Nuridawani, Munzir, S., \& Saiman. (2015). Peningkatan Kemampuan Penalaran Matematis dan Kemandirian Belajar Siswa Madrasah Tsanawiyah ( MTs ) melalui Pendekatan Contextual Teaching and Learning ( CTL ). Jurnal Didaktik Matematika, 2(2), 59-71. 